\title{
Aksesibilitas Pariwisata Bagi Difabel di Kota Surakarta (Studi Evaluasi Peraturan Menteri Pekerjaan Umum Nomor 30 Tahun 2006 Tentang Pedoman Teknis Fasilitas Dan Aksesibilitas Pada Bangunan Gedung Dan Lingkungan)
}

\author{
Tourism Accessibility For Disabled in Surakarta \\ (Evaluation Study of Public Works Ministerial Regulation No. 30 Year 2006 on Technical \\ Guidelines Amenities and Accessibility In the Building and Environment) \\ Rina Herlina Haryanti, Candra Sari \\ Program Studi Ilmu Administrasi Negara Universitas Sebelas Maret
}

\begin{abstract}
Abstrak
Penelitian ini bertujuan untuk melihat kelengkapan fasilitas dan sarana serta aksesibilitasnya yang ada di lokasi wisata yang ada di Kota Surakarta yakni Taman Balekambang, Taman Satwa Taru Jurug dan Taman Hiburan Rakyat (THR) Sriwedari. Kelengkapan fasilitas dan sarana yang ada di lokasi wisata ini dinilai berdasarkan Peraturan Menteri Pekerjaan Umum Nomor 30 Tahun 2006 Tentang Pedoman Teknis Fasilitas dan Aksesibilitas Pada Bangunan Gedung dan Lingkungan. Penelitian ini menilai apakah pariwisata di Surakarta telah aksesibel atau belum dan dilihat berdasarkan asas-asas aksesibilitas. Metode penelitian yang digunakan adalah penelitian deskriptif kualitatif dengan teknik pengumpulan data menggunakan teknik observasi, wawancara dan dokumen.Untuk mendapatkan data yang valid, penelitian ini mengunakan triangulasi sumber data.Sedangkan teknik analisis data menggunakan teknik analisis interaktif.

Fasilitas yang dilihat dan dinilai berdasarkan Peraturan Menteri Pekerjaan Umum Nomor 30 Tahun 2006 Tentang Pedoman Teknis Fasilitas dan Aksesibilitas Pada Bangunan Gedung dan Lingkungan tersebut yakni ukuran dasar ruang, jalur pedestrian, jalur pemandu, area parkir, ramp, serta rambu dan marka.Hasil penelitian menunjukkan bahwa keadaan fasilitas dan sarana yang ada di lokasi wisata yakni Taman Balekambang, Taman Satwa Taru Jurug dan Taman Hiburan Rakyat (THR) Sriwedari belum lengkap dan sesuai dengan kebijakan. Ketidaklengkapan fasilitas ini menunjukkan bahwa lokasi wisata yang ada tidak aksesibel bagi difabel.Ini menjadikan aksesibilitas pariwisata yang ada di Surakarta belum terwujud.
\end{abstract}

Kata Kunci :Aksesibilitas, Kelengkapan fasilitas, Pariwisata, Difabel

\begin{abstract}
This study aims to look at the complete facilities and their accessibility in existing tourist sites in the city of Surakarta namely Taman Balekambang, Taman Satwa Taru Jurug and Taman Hiburan Rakyat (THR) Sriwedari. Completeness of facilities and existing facilities at tourist sites is assessed based on the Minister of Public Works No. 30 Year 2006 on Technical Guidelines and Accessibility Facility On Building and Environment. This study assessed
\end{abstract}


whether tourism in Surakarta was accessible or not and viewed based principles of accessibility. The method used is descriptive qualitative research with data collection technique using observation, interviews and documents. To obtain valid data, this study using triangulation of data sources. While data analysis techniques using interactive analysis techniques.

Facilities were seen and assessed based on the Public Works Ministerial Regulation No. 30 Year 2006 on Technical Guidelines and Accessibility Facility Building and Environment On the basis of the size of the room, pedestrian paths, guide lines, parking areas, ramps, and traffic signs and markings. The results showed that the state of the facilities and existing facilities at tourist sites namely Taman Balekambang, Taman Satwa Taru Jurug and Taman Hiburan Rakyat (THR) Sriwedari yet complete and in accordance with policy. Incompleteness of this facility shows that tourist sites are not accessible for the disabled. It makes the accessibility of tourism in Surakarta not materialized.

Keywords: Accessibility, Completeness facilities, Tourism, Disability.

\section{Pendahuluan}

Aksesibilitas merupakan kemudahan yang disediakan bagi semua orang termasuk penyandang difabel guna mewujudkan kesamaan kesempatan dalam segala aspek kehidupan. Dapat dikatakan bahwa berbagai bidang harus dapat digunakan oleh penyandang difabel agar mereka mampu untuk mendapatkan kesempatan, kesetaraan, dan hak yang sama dalam kehidupan. Aksesibilitas khususnya bagi penyandang difabel sebagai salah satu hal yang telah di bahas dalam CPRD juga telah diatur di berbagai peraturan pemerintah. seperti Peraturan Menteri Pekerjaan Umum No. 30 Tahun 2006 Tentang Pedoman Teknis Fasilitas dan Aksesibilitas Pada Bangunan Gedung dan Lingkungan, serta Undang-Undang Nomor 4 Tahun 1997 tentang Penyandang Cacat. Namun masih banyak contoh-contoh permasalahan aksesibilitas di Indonesia sehingga menjadi hal yang menarik untuk dievaluasi.

Dalam pasal 10 ayat 1 dan 2 UndangUndang No 4 Tahun 1997 yang menyebutkan bahwa penyandang difabel mendapat kesamaan kesempatan dalam segala aspek kehidupan melalui penyediaan aksesibilitas, Ini berarti terpenuhinya sarana dan fasilitas yang aksesibel bagi penyandang difabel merupakan hal yang harus dan wajib dilaksanakan untuk menjamin kesamaan kesempatan hidup. Dari penyediaan dan peningkatan sarana, fasilitas maupun pelayanan yang aksesibel bagi penyandang difabel, hanya beberapa bidang yang sebagian masyarakat fokuskan untuk aksesibilitas difabel.Bidang pariwisata sebagai salah satu hal yang jarang diperhatikan untuk dinilai terkait penyediaan fasilitas yang aksesibel.

Surakarta yang memiliki banyak penghargaan dalam bidang pariwisata sehingga tempat tempat wisata yang dikelola menarik perhatian baik dari wisatawan lokal maupun mancanegara. Yang menjadi perhatian adalah apakah Kota Surakarta yang dikenal sebagai kota yang mendapat penghargaan yang sedemikian prestige dalam bidang Pariwisata dan dalam pelayanannya, juga telah memperhatikan 
Rina Herlina Haryanti, Candra Sari: Aksesibilitas Pariwisata Bagi Difabel di Kota Surakarta (Studi Evaluasi

Peraturan Menteri Pekerjaan Umum Nomor 30 Tahun 2006 Tentang Pedoman Teknis Fasilitas Dan Aksesibilitas Pada Bangunan Gedung Dan Lingkungan)

dan menyediakan kebutuhan penyandang difabel dalam bidang pariwisata. Apakah dari sekian banyak tempat wisata yang ada di Kota Surakarta, seluruhnya telah memenuhi standart yang telah ditetapkan dalam peraturan menteri sehingga dapat dikatakan aksesibel bagi penyandang difabel. Untuk itu penulis akan melakukan studi evaluasi berdasarkan Peraturan Menteri Pekerjaan Umum No. 30 Tahun 2006 terkait dengan aksesibilitas sarana dan fasilitas bangunan atau tempat wisata yang ada bagi penyandang difabel di Kota Surakarta. Aksesibilitas ini juga akan menggunakan asas kemudahan, kegunaan, keselamatan dan kemandirian.

\section{Kajian Pustaka}

\section{A. Studi Evaluasi}

Secara umum evaluasi dapat dikatakan sebagai kegiatan yang menyangkut estimasi atau penilaian kebijakan yang mencangkup substansi, implementasi dan dampak (Winarno: 2008). Dalam proses implementasi, pemerintah menginterpretasikan regulasi tersebut menjadi program, dimana dalam pelaksanaan program biasanya diikuti oleh serangkaian tindakan fisik sehingga menimbulkan konsekuensi baru berupa hasil, efek atau dampak (Wibawa : 1994). Sehingga untuk mengetahui bagaimana konsekuensi baru yang dihasilkan dari implementasi kebijakan tersebut, maka perlu dilakukan evaluasi terhadap kebijakan. Evaluasi kebijakan memiliki empat fungsi sebagai berikut yakni ; (1) Eksplanasi dimana dilihat realitas pelaksanaan program dan dapat dibuat suatu generalisasi tentang pola-pola hubungan antar berbagai dimensi yang diamatinya sehingga diidentifikasi tujuantujuan apa dari progam yang dikajinya yang potensial untuk dicapai, dan kenapa serta bagaimana tujuan itu harus tercapai, (2) Kepatuhan dimana dapat diketahui apakah tindakan yang dilakukan oleh para pelaku sesuai dengan standart dan prosedur yang ditetapkan oleh kebijakan, (3) Auditing dimana dilihat apakah output benar-benar sampai ketangan kelompok sasaran maupun penerima lain yang dimaksud oleh pembuat kebijakan, dan (4) AkuntingDimana dapat diketahui apa akibat sosial-ekonomi dari kebijakan tersebut (Wibawa : 1994).

Melakukan studi evaluasi kebijakan berarti melakukan penilaian terhadap suatu kebijakan atau peraturan yang telah diimplementasikan. Namun di dalam implementasi suatu kebijakan terkadang ada beberapa hal yang mempengaruhi berhasil atau tidaknya sebuah implementasi yang dapat dilihat setelah dilakukan penilaian melalui studi evaluasi. George Edward III dalam Juliartha (2009) mengungkapkan ada 4 faktor yang mempengaruhi keberhasilan atau kegagalan dalam implementasi kebijakan yakni (1) Komunikasi, (2) Sumber daya, Disposisi, dan (4) Struktur birokratik.

Maarse dalam Solichin (1997) menyatakan bahwa keberhasilan kebijakan ditentukan oleh yang pertama isi kebijakan apakah jelas atau tidak, samar atau tidak. Kedua yaitu isu kebijakan apakah kebijakan tersebut tegas dalam aturan atau tidak, yang ketiga adalah informasi terkait kejelasan gambaran kebijakan. Yang keempat adalah dukungan terkait dengan kebijakan tersebut. Sedangkan James Anderson dalam Sunggoro (1994) juga berpendapat ada beberapa hal yang mempengaruhi kegagalan implementasi yakni: (1) Konsep ketidakpatuhan terhadap hukum atau hukum yang ada kurang mengikat, (2) Gagasan atau pemikiran yang bertentangan dengan kebijakan, (3) Keinginan untuk mencari keuntungan sehingga melawan hukum, (4) Hukum atau kebijakan yang ada saling bertentangan satu sama lain, (5) Kebijakan yang ada bertentangan dengan 
nilai yang ada dimasyarakat.

\section{B. Difabel dan Aksesibilitas}

Difabel merupakan kata yang merujuk pada istilah berbahasa ingris Different Ability yang kemudian disingkat menjadi Difable. Kata difabel dipergunakan untuk menggantikan istilah penyandang cacat yang memiliki perspektif yang negatif dan membentuk opini bahwa kecacatan patut dikasihani dan tidak bermartabat. Istilah Different Ablility yang memiliki arti perbedaan kemampuan dianggap lebih humanis dan dipandang tidak mendiskriminasi serta dianggap mampu melindungi dan menjamin hak-hak asasi mereka sebagai manusia (Tarsidi, 2009).

Undang-Undang Negara Republik Indonesia Nomor 4 Tahun 1997, difabel adalah setiap orang yang mempunyai kelainan fisik dan/atau mental, yang dapat mengganggu atau merupakan rintangan dan hambatan baginya untuk melakukan secara selayaknya. Ladner (2014) menyebutkan bahwa difabel mungkin terjadi karena bawaan sejak lahir, kecelakaan, perang, penyakit atau karena prosedur medis yang sembarangan. Ada tiga jenis difabel : yakni fisik, mental dan campuran. Nielsen (2013) menjelaskan Difabel fisik terdiri atas Visual disabilities (tunanetra), Hearing disabilies (tunarungu), Mobility disabilities (tunadhaksa). Difabel mental terdiri atas retardasi mental, gangguan psikiatrik fungsional, alkoholisme, gangguan mental organik dan epilepsi (Demartoto, 2005 : 11).

Aksesibilitas merupakan salah satu hak bagi difabel dimana hal tersebut tertuang dalam Undang-Undang No 4 Tahun 1997. Selain itu aksesibilitas bagi difabel juga menjadi hal penting karena merupakan bagian dalam Opsional Protocol dari CRPD.Aksesibilitas dalam Kamus Besar Bahasa Indonesia berarti sesuatu atau hal yang dapat diakses.Sedangkan dalam kata accessibility memiliki artian tingkat kemudahan untuk diakses.Aksesibilitas dibagi menjadi dua macam, yakni (1) Aksesibilitas fisik yang meliputi layanan yang terkit dengan perencanaan dan peruntukan pembangunan kawasan kota serta fasilitas publik, dan (2) Aksesibilitas non fisikdimana warga berhak memperoleh kesempatan yang sama dalam pendidikan dan pekerjaan. Dalam menilai aksesibilitas fisik, maka ada beberapa asas yang harus diperhatikan yakni keselamatan, kemudahan, kegunaan, kemandirian.

1. Keselamatan, yaitu setiap bangunan yang bersifat umum dalam suatu lingkungan terbangun harus memperhatikan keselamatan bagi semua orang.

2. Kemudahan, yaitu setiap orang dapat mencapai semua tempat atau bangunan yang bersifat umum dalam suatu lingkungan.

3. Kegunaan, yaitu setiap orang harus dapat mempergunakan semua tempat atau bangunan yang bersifat umum dalam suatu lingkungan.

4. Kemandirian, yaitu setiap orang harus bisa mencapai, masuk dan mempergunakan semua tempat atau bangunan yang besifat umum dalam suatu lingkungan dengan tanpa membutuhkan bantuan dari orang lain.

\section{Pariwisata}

Di Indonesia pariwisata telah tumbuh menjadi industri dengan prospek yang menjanjikan dalam Pembangunan Nasional (Spillane: 1994). Pariwisata sendiri merupakan berbagai macam kegiatan wisata dan didukung berbagai fasilitas serta layanan yang disediakan oleh masyarakat, pengusaha, Pemerintah dan Pemerintah Daerah.Spillane (1994) juga menyebutkan 
bahwa fasilitas dan infrastruktur menjadi hal atau bagaian yang sangat penting dalam penyelenggaraan pariwisata.

Dalam Undang-undang Nomor 10 Tahun 2009 juga menyebutkan asas-asas yang ada dalam pariwasata, yakni : Manfaat, Kekeluargaan, Adil dan merata, Keseimbangan, Kemandirian, Kelestarian, Partisipatif, Berkelanjutan, Demokratis, Kesetaraan, dan Kesatuan. Asas-asas yang ada dalam pariwisata juga memuat beberapa tujuan yang nantinya akan dicapai dengan penyelenggaraan aksesibilitas. pariwisata yang menyediakan sarana prasana yang aksesibel akan mempermudah mencapai keadilan, kesetaraan dan kemandirian bagi masyarakat. Dalam jurnalnya Darcy (2009) menyebutkan bahwa :

"Accessible tourism enables people with access requirements, including mobility, vision, hearing and cognitive dimensions of access, to function independently and with equity and dignity through the delivery of universally designed tourismproducts, services and environments. This definition is inclusive of all people including those travelling with children in prams, people with disabilities and seniors."

\section{Aksesibilitas Difabel dalam Peraturan Menteri Pekerjaan Umum Nomor 30 Tahun 2006}

Peraturan Menteri Pekerjaan Umum Nomor 30 Tahun 2006ini dibuat untuk memberikan acuan bagi kegiatan pembangunan yang meliputi perancangan dan pelaksanaan konstruksi serta pemanfaatan bangunan gedung dan lingkungan yang aksesibel bagi semua orang dengan mengutamakan semua orang termasuk difabel. Tujuan kebijakan ini adalah mewujudkan kesamaan, kesetaraan, kedudukan dan hak kewajiban serta peningkatan peran difabel. Untuk itu, peningkatan sarana dan fasilitas yang memadai, terpadu atau inklusif dan berkesinambungan diharapkan dapat mencapai kemandirian dan kesejahteraan bagi difabel.

Persyaratan fasilitas yang harus aksesibel pada bangunan gedung dan lingkungan meliputi : Ukuran dasar ruang; Jalur pedestrian; Jalur pemandu; Area parkir; Pintu; Ram; Tangga; Lif; Lif tangga (stairway lift); Toilet; Pancuran; Wastafel; Telepon; Perlengkapan dan Peralatan Kontrol; Perabot; Rambu dan Marka. Sedangkan tapak bangunan dan lingkungan diluar bangunan harus memperhatikan aksesibilitas pada fasilitas berikut: Ukuran lantai bebas; Jalur pedestrian; Jalur pemandu; Area parkir; Ramp; Rambu dan Marka.

\section{Metode Penelitian}

Metode penelitian yang digunakan adalah penelitian deskriptif kualitatif. Lokasi penelitian di Kota Surakarta dengan tempat wisata yang diteliti adalah :

1. Taman Satwa Taru Jurug

2. Taman Hiburan Rakyat (THR) Sriwedari dan

3. Taman Balekambang.

Teknik pengumpulan data menggunakan teknik observasi dan wawancara serta dokumen. Uji validitas menggunakan triangulasi data dan metode. Teknik analisis data yang digunakan adalah teknk analisis data interaktif dengan melakukan reduksi data, kemudian melakukan pengolahan data dan penyajian data dan kemudian dilakukan penarikan simpulan. 


\section{Pembahasan}

\section{A. Kelengkapan Sarana dan Fasilitas Tempat Wisata bagi Difabel}

Penelitian mengenai kelengkapan sarana dan fasilitas bagi difabel yang harus ada khususnya bagi lingkungan atau luar gedung, akan melihat dari enam hal berikut, yakni ukuran dasar ruang, jalur pedestrian, jalur pemandu, area parkir, penyediaan ramp, serta rambu dan marka. Hal tersebut sesuai dengan Peraturan Menteri Pekerjaan Umum No. 30 Tahun 2006. Dapat dilihat pada tabel dibawah ini:

Tabel 1. Kelengkapan Sarana dan Fasilitas Tempat Wisata bagi Difabel

\begin{tabular}{|c|c|c|c|c|c|c|c|c|c|}
\hline \multirow{3}{*}{ 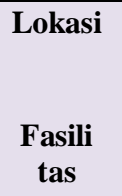 } & \multicolumn{3}{|c|}{ Taman Balekambang } & \multicolumn{3}{|c|}{ Taman Satwa Taru Jurug } & \multicolumn{3}{|c|}{ THR Sriwedari } \\
\hline & \multicolumn{2}{|c|}{ Kondisi } & \multirow{2}{*}{$\begin{array}{c}\text { Keter } \\
\text { sedia } \\
\text { an }\end{array}$} & \multicolumn{2}{|c|}{ Kondisi } & \multirow{2}{*}{$\begin{array}{c}\text { Keter } \\
\text { sedia } \\
\text { an }\end{array}$} & \multicolumn{2}{|c|}{ Kondisi } & \multirow{2}{*}{$\begin{array}{c}\text { Keter } \\
\text { sedia } \\
\text { an }\end{array}$} \\
\hline & Seharusnya & $\begin{array}{c}\text { Senyata } \\
\text { nya }\end{array}$ & & Seharusnya & $\begin{array}{c}\text { Senyata } \\
\text { nya }\end{array}$ & & Seharusnya & $\begin{array}{c}\text { Senyata } \\
\text { nya }\end{array}$ & \\
\hline $\begin{array}{l}\text { Ukuran } \\
\text { Dasar } \\
\text { Ruang }\end{array}$ & $\begin{array}{l}\text { - Ukuran } \\
\text { ruang ke } \\
\text { depan- } \\
\text { atas- } \\
\text { samping } \\
\text { minimal } \\
180 \mathrm{~cm}\end{array}$ & $\begin{array}{l}\text { Sesuai } \\
\text { tetapi } \\
\text { terdapat } \\
\text { ranting } \\
\text { pohon } \\
\text { yang } \\
\text { rendah. }\end{array}$ & $v$ & $\begin{array}{l}\text { - Ukuran } \\
\text { ruang ke } \\
\text { depan- } \\
\text { atas- } \\
\text { samping } \\
\text { minimal } \\
180 \mathrm{~cm}\end{array}$ & - Sesuai & $v$ & $\begin{array}{l}\text { - Ukuran } \\
\text { ruang ke } \\
\text { depan- } \\
\text { atas- } \\
\text { samping } \\
\text { minimal } \\
180 \mathrm{~cm}\end{array}$ & $\begin{array}{l}\text { - Tidak } \\
\text { Sesuai }\end{array}$ & - \\
\hline $\begin{array}{l}\text { Jalur } \\
\text { Pedestri } \\
\text { an }\end{array}$ & $\begin{array}{l}\text { - Jauh dari } \\
\text { lalu lintas } \\
\text { kendaraan } \\
\text { - Memiliki } \\
\text { jalur } \\
\text { landai } \\
\\
\\
\text { - Tidak } \\
\text { licin } \\
\text { - Dapat } \\
\text { dilewati } \\
\text { dua jalur } \\
\text { tanpa } \\
\text { terjadi } \\
\text { benturan } \\
\text { - Penera } \\
\text { ngan } \\
\text { memadai }\end{array}$ & $\begin{array}{l}\text { - Sesuai } \\
\text { - Tidak } \\
\text { sesuai } \\
\text { di } \\
\text { bebera- } \\
\text { pa } \\
\text { tempat } \\
\text { - Sesuai } \\
\text { - Sesuai } \\
\\
\text { - Sesuai }\end{array}$ & $v$ & $\begin{array}{l}\text { - Jauh dari } \\
\text { lalu lintas } \\
\text { kendaraan } \\
\text { - Memiliki } \\
\text { jalur } \\
\text { landai } \\
\\
\\
\\
\text { - Tidak } \\
\text { licin } \\
\text { - Dapat } \\
\text { dilewati } \\
\text { dua jalur } \\
\text { tanpa } \\
\text { terjadi } \\
\text { benturan } \\
\text { - Peneranga } \\
\text { n } \\
\text { memadai }\end{array}$ & $\begin{array}{l}\text { - Sesuai } \\
\text { - Tidak } \\
\text { Sesuai } \\
\text { - Sesuai } \\
\text { - Tidak } \\
\text { Sesuai } \\
\text { - Sesuai }\end{array}$ & 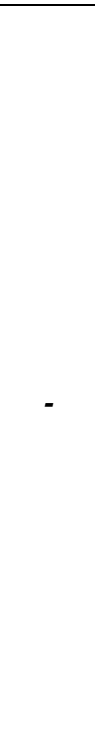 & $\begin{array}{l}\text { - Jauh dari } \\
\text { lalu lintas } \\
\text { kendaraan } \\
\text { - Memiliki } \\
\text { jalur } \\
\text { landai } \\
\\
\\
\text { - Tidak } \\
\text { licin } \\
\text { - Dapat } \\
\text { dilewati } \\
\text { dua jalur } \\
\text { tanpa } \\
\text { terjadi } \\
\text { benturan } \\
\text { - Penerang- } \\
\text { an } \\
\text { memadai }\end{array}$ & $\begin{array}{l}\text { - Sesuai } \\
\text { - Tidak } \\
\text { Sesuai, } \\
\text { jumlahn } \\
\text { ya } \\
\text { masih } \\
\text { kurang } \\
\text { - Sesuai } \\
\text { - Tidak } \\
\text { Sesuai } \\
\\
\\
\text { - Tidak } \\
\text { Sesuai }\end{array}$ & - \\
\hline $\begin{array}{l}\text { Jalur } \\
\text { Peman- } \\
\text { du }\end{array}$ & $\begin{array}{l}\text { - Menyedia } \\
\text { kan jalur } \\
\text { pemandu } \\
\text { dengan } \\
\text { tekstur } \\
\text { ubin } \\
\text { sesuai } \\
\text { kriteria }\end{array}$ & $\begin{array}{l}\text { Tidak } \\
\text { Tersedia }\end{array}$ & - & $\begin{array}{l}\text { - Menyedia } \\
\text { kan jalur } \\
\text { pemandu } \\
\text { dengan } \\
\text { tekstur } \\
\text { ubin } \\
\text { sesuai } \\
\text { kriteria }\end{array}$ & $\begin{array}{l}\text { Tidak } \\
\text { Tersedia }\end{array}$ & - & $\begin{array}{l}\text { Menyedia } \\
\text { kan jalur } \\
\text { pemandu } \\
\text { dengan } \\
\text { tekstur } \\
\text { ubin } \\
\text { sesuai } \\
\text { kriteria }\end{array}$ & $\begin{array}{l}\text { Tidak } \\
\text { Tersedia }\end{array}$ & - \\
\hline
\end{tabular}


Rina Herlina Haryanti, Candra Sari: Aksesibilitas Pariwisata Bagi Difabel di Kota Surakarta (Studi Evaluasi Peraturan Menteri Pekerjaan Umum Nomor 30 Tahun 2006 Tentang Pedoman Teknis Fasilitas Dan Aksesibilitas Pada Bangunan Gedung Dan Lingkungan)

\begin{tabular}{|c|c|c|c|c|c|c|c|c|c|}
\hline & $\begin{array}{l}\text { - Berdekata } \\
\text { n dengan } \\
\text { kursi } \\
\text { taman, } \\
\text { tempat } \\
\text { sampah } \\
\text { dan } \\
\text { telepon } \\
\text { umum } \\
\text { - Menuju } \\
\text { elemen } \\
\text { seperti } \\
\text { toilet } \\
\text { umum, } \\
\text { ramp, } \\
\text { parkir dan } \\
\text { rambu } \\
\text { atau } \\
\text { marka }\end{array}$ & $\begin{array}{l}\text { Tidak } \\
\text { Tersedia }\end{array}$ & & 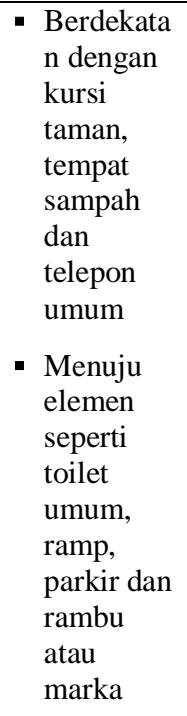 & $\begin{array}{l}\text { Tidak } \\
\text { Tersedia }\end{array}$ & & $\begin{array}{l}\text { - Berdekata } \\
\text { n dengan } \\
\text { kursi } \\
\text { taman, } \\
\text { tempat } \\
\text { sampah } \\
\text { dan } \\
\text { telepon } \\
\text { umum } \\
\text { - Menuju } \\
\text { elemen } \\
\text { seperti } \\
\text { toilet } \\
\text { umum, } \\
\text { ramp, } \\
\text { parkir dan } \\
\text { rambu } \\
\text { atau } \\
\text { marka }\end{array}$ & $\begin{array}{l}\text { Tidak } \\
\text { Tersedia }\end{array}$ & \\
\hline $\begin{array}{l}\text { Area } \\
\text { Parkir }\end{array}$ & $\begin{array}{l}\text { Parkir } \\
\text { khusus } \\
\text { difabel } \\
\text { yang } \\
\text { ditandai } \\
\text { dengan } \\
\text { adanya } \\
\text { marka } \\
\text { khusus }\end{array}$ & $\begin{array}{l}\text { - Tidak } \\
\text { Tersedia }\end{array}$ & - & $\begin{array}{l}\text { Parkir } \\
\text { khusus } \\
\text { difabel } \\
\text { yang } \\
\text { ditandai } \\
\text { dengan } \\
\text { adanya } \\
\text { marka } \\
\text { khusus }\end{array}$ & $\begin{array}{l}\text { - Tidak } \\
\text { Tersedia }\end{array}$ & - & $\begin{array}{l}\text { Parkir } \\
\text { khusus } \\
\text { difabel } \\
\text { yang } \\
\text { ditandai } \\
\text { dengan } \\
\text { adanya } \\
\text { marka } \\
\text { khusus }\end{array}$ & $\begin{array}{l}\text { - Tidak } \\
\text { Tersedia }\end{array}$ & - \\
\hline $\begin{array}{l}\text { Penyedi } \\
\text { aan } \\
\text { Ramp }\end{array}$ & $\begin{array}{l}\text { Ramp } \\
\text { yang ada } \\
\text { memiliki } \\
\text { kelandai- } \\
\text { an yang } \\
\text { tidak } \\
\text { terlalu } \\
\text { tajam }\end{array}$ & - Sesuai & $v$ & $\begin{array}{l}\text { - Ramp } \\
\text { yang ada } \\
\text { memiliki } \\
\text { kelandai- } \\
\text { an yang } \\
\text { tidak } \\
\text { terlalu } \\
\text { tajam }\end{array}$ & $\begin{array}{l}\text { - Tidak } \\
\text { tersedia }\end{array}$ & - & $\begin{array}{l}\text { Ramp } \\
\text { yang ada } \\
\text { memiliki } \\
\text { kelandai - } \\
\text { an yang } \\
\text { tidak } \\
\text { terlalu } \\
\text { tajam }\end{array}$ & $\begin{array}{l}\text { Sesuai, } \\
\text { jumlah } \\
\text { masih } \\
\text { kurang }\end{array}$ & $v$ \\
\hline $\begin{array}{l}\text { Rambu } \\
\text { dan } \\
\text { Marka }\end{array}$ & $\begin{array}{l}\text { - Menunjuk } \\
\text { pada arah } \\
\text { fasilitas } \\
\text { bagi } \\
\text { difabel } \\
\text { - Ditempat } \\
\text { kan bebas } \\
\text { pandang } \\
\text { tanpa } \\
\text { pengha- } \\
\text { lang } \\
\text { - Pencaha- } \\
\text { yaan baik } \\
\text { - Tidak } \\
\text { menggang } \\
\text { gu arus } \\
\text { pejalan } \\
\text { kaki }\end{array}$ & $\begin{array}{l}\text { - Tidak } \\
\text { tersedia } \\
\text { - Tidak } \\
\text { Tersedia } \\
\\
\text { - Tidak } \\
\text { Tersedia } \\
\text { - Tidak } \\
\text { Tersedia }\end{array}$ & - & $\begin{array}{l}\text { - Menunjuk } \\
\text { pada arah } \\
\text { fasilitas } \\
\text { bagi } \\
\text { difabel } \\
\text { - Ditempat- } \\
\text { kan bebas } \\
\text { pandang } \\
\text { tanpa } \\
\text { pengha- } \\
\text { lang } \\
\text { - Pencaha- } \\
\text { yaan baik } \\
\text { - Tidak } \\
\text { menggang } \\
\text { gu arus } \\
\text { pejalan } \\
\text { kaki }\end{array}$ & $\begin{array}{l}\text { - Tidak } \\
\text { tersedia } \\
\text { - Tidak } \\
\text { Tersedia } \\
\\
\text { - Tidak } \\
\text { Tersedia } \\
\text { - Tidak } \\
\text { Tersedia }\end{array}$ & - & $\begin{array}{l}\text { - Menunjuk } \\
\text { pada arah } \\
\text { fasilitas } \\
\text { bagi } \\
\text { difabel } \\
\text { - Ditempat- } \\
\text { kan bebas } \\
\text { pandang } \\
\text { tanpa } \\
\text { pengha- } \\
\text { lang } \\
\\
\text { - Pencaha- } \\
\text { yaan baik } \\
\text { - Tidak } \\
\text { menggang } \\
\text { gu arus } \\
\text { pejalan } \\
\text { kaki }\end{array}$ & $\begin{array}{l}\text { - Tidak } \\
\text { Tersedia } \\
\\
\text { - Tidak } \\
\text { Tersedia }\end{array}$ & - \\
\hline
\end{tabular}

Sumber : Diolah oleh peneliti berdasarkan hasil penelitian. 


\section{B. Aksesibilitas Sarana dan Fasilitas Pariwisata Bagi Difabel Di Surakarta}

Selain pemenuhan fasilitas dan sarana yang ada di lokasi-lokasi wisata harus disediakan secara lengkap, harus diperhatikan pula apakah sarana dan fasilitas yang ada di lokasi wisata tersebut telah aksesibel bagi difabel.Dalam Peraturan Menteri Pekerjaan Umum No.30 Tahun 2006 bab II Pasal 3 ayat (1) juga menjelaskan bahwa penyediaan fasilitas dan aksesibilitas merupakan suatu keharusan.Penting pula untuk mengetahui apa itu aksesibilitas, khususnya sarana bagi difabel. Jika akan melihat aksesibilitas terkait dengan fasilitas atau sarana bagi difabel, maka hal pertama yang harus diperhatikan adalah apakah fasilitas dan sarana yang tersedia dapat digunakan oleh semua orang khususnya difabel secara mudah, tidak membahayakan, dapat menggunakan fasilitas tersebut tanpa bantuan orang lain. Apabila suatu fasilitas atau sarana telah memenuhi asas tersebut maka dapat dikatakan bahwa fasilitas dan sarana yang tersedia telah aksesibel.

Salah satu faktor penting yang mempengarui aksesibel atau tidaknya suatu fasilitas dan sarana adalah apakah pengguna merasa nyaman apabila sedang menggunakan atau menikmati fasilitas dan sarana yang disediakan.Meskipun beberapa fasilitas dan sarana telah ada namun apabila sarana dan fasilitas tersebut tidak dapat digunakan secara nyaman dan mudah oleh pengguna maka belum dapat dikatakan aksesibel.

Dari daftar kelengkapan fasilitas yang ada di dalam tabel yang ditampilkan sebelumnya, dapat dilihat bahwa ketersediaan sarana dan fasilitas yang ada di ketiga lokasi wisata yang ada di Surakarta yakni Taman Satwa Taru Jurug, Taman Balekambang, dan Taman Hiburan Rakyat (THR) Sriwedari belum terpenuhi kelengkapannya serta belum sesuai dengan Peraturan Menteri Pekerjaan Umum No.30 Tahun 2006. Untuk lebih singkatnya, aksesibilitas fasilitas dan sarana yang telah tersedia di lokasi wisata adalah sebagai berikut :

Tabel 2. Aksesibilitas Fasilitas dan Sarana yang Tersedia

\begin{tabular}{|l|l|l|l|l|l|}
\hline \multicolumn{2}{|c|}{ Taman Satwa Taru Jurug } & \multicolumn{2}{c|}{ Taman Balekambang } & \multicolumn{2}{c|}{ THR Sriwedari } \\
\hline \multicolumn{1}{|c|}{ Fasilitas } & Aksesibilitas & \multicolumn{1}{|c|}{ Fasilitas } & Aksesibilitas & \multicolumn{1}{c|}{ Fasilitas } & Aksesibilitas \\
\hline - Ukuran & - Tidak & - Ukuran Dasar & - Aksesibel & - Ramp & - Aksesibel \\
dasar ruang & Aksesibel & Ruang & & & \\
& & - Jalur & - Aksesibel & & \\
& & Pedestrian & & & \\
& & - Toilet & - Aksesibel & & \\
& & - Ramp & - Tidak & & \\
& & & Aksesibel & & \\
& & & & & \\
& & & & & \\
& & & &
\end{tabular}

Sumber : Diolah oleh peneliti berdasarkan hasil penelitian.

\section{Ketidaktersediaan Sarana dan Fasilitas yang Aksesibel Bagi Difabel: Sebuah Analisis}

Setelah dilakukan penelitian maka dapat dilihat bahwa fasilitas bagi difabel yang ada di tiga lokasi wisata yang ada di Surakarta yakni Taman Balekambang, Taman Satwa Taru Jurug dan Taman Hiburan Rakyat (THR) Sriwedari belum tersedia dengan baik sehingga membuat tidak aksesibelnya pariwisata bagi difabel. Keadaan fasilitas 
Rina Herlina Haryanti, Candra Sari: Aksesibilitas Pariwisata Bagi Difabel di Kota Surakarta (Studi Evaluasi

Peraturan Menteri Pekerjaan Umum Nomor 30 Tahun 2006 Tentang Pedoman Teknis Fasilitas Dan Aksesibilitas Pada Bangunan Gedung Dan Lingkungan)

yang ada di lokasi wisata tersebut tidak sesuai dengan apa yang semestinya ada yang diatur dalam Peraturan Menteri Pekerjaan Umum No.30 Tahun 2006. Hal ini menunjukkan bahwa kebijakan ini tidak diimplementasikan dengan baik sebab masih banyak terjadi ketidaksesuaian antara apa yang diatur dalam kebijakan dan apa yang diimplementasikan. Dapat dikatakan implementasi kebijakan ini telah gagal menerapkan fungsi kepatuhan sebagai salah satu fungsi di dalam studi evaluasi.

Undang-undang mengatur bahwa wajib adanya perlakuan yang sama terhadap difabel baik dalam hal peran, pembangunan maupun menikmati hasil dari pembangunan tersebut. Selain itu, Opsional Protocol dari CRPD juga menyebutkan bahwa pentingnya tidak ada diskriminasi terhadap difabel dan juga adanya penyediaan aksesibilitas bagi difabel. Namun apabila yang terjadi adalah kegagalan penyediaan pariwisata yang aksesibel bagi difabel, dapat dikatakan bahwa apa yang diatur dalam undang-undang dan prinsip-prinsip yang ada di dalam CRPD tidak dilaksanakan dengan baik sehingga belum mampu mewujudkan apa yang disebut dengan kesetaraan bagi difabel dalam segala aspek kehidupan.

Pariwisata merupakan salah satu aspek yang harus dipenuhi aksesibilitasnya. Lokasi wisata juga merupakan salah satu bentuk fasilitas publik yang harus dijamin aksesibilitasnya. Namun berdasarkan penelitian ini lokasi-lokasi wisata yang ada di Surakarta belum mampu menyediakan wisata yang aksesibel bagi difabel. Temuan ini sejalan dengan hasil penelitian yang dilakukan oleh Putri (2011) yang menemukan bahwa banyak fasilitas di kota Surakarta yang belum secara baik dapat diakses oleh difabel karena permasalahan desain teknis, kondisi yang tidak kondusif dan fasilitas yang belum memadai ditambah kurangnya perawatan. Hasil penelitian ini juga mendukung tulisan Simon Darcy
(2009) dimana ia menyimpulkan bahwa penting untuk melihat penyediaan pariwisata yang mudah diakses bagi difabel dan juga diperlukan pemahaman yang baik terkait tujuan aksesibilitas dalam pariwisata. Sebab dalam penelitian ini ditemukan pula bahwa ada kemungkinankemungkinan kurangnya pemahaman dari pengelola tentang penyelenggaraan pariwisata yang aksesibel dan pentingnya kesetaraan bagi difabel dalam segala aspek kehidupan termasuk pariwisata.

Kegagalan menyediakan fasilitas dan sarana yang aksesibel bagi difabel dalam pariwisata juga diindikasi disebabkan oleh beberapa sebab dan faktor.Berdasarkan deskripsi dan hasil observasi yang telah dilakukan didapat beberapa temuan yang dimungkinkan menjadi salah satu penyebab gagalnya kebijakan Peraturan Menteri Pekerjaan Umum No 30 Tahun 2006 ini dilaksanakan. Temuan yang pertama yakni kurangnya data terkait dengan kunjungan atau inventaris fasilitas bagi difabel yang dimiliki oleh ketiga lokasi wisata tersebut, atau bahkan dapat dikatakan sama sekali tidak ada data terkait kedua hal tersebut. Ini menjadikan pihak pengelola tidak mengetahui apakah fasilitas yang dimiliki telah sesuai dengan aturan atau belum. Hal ini kemungkinan terjadi karena masih kurangnya respect atau minat dan kesadaran dari pengelola terkait dengan aksesibilitas dan pemenuhan hak-hak difabel. Kekurangan baik berupa data atau kesadaran dari pihak pengelola ini dimungkinkan juga terjadi karena pihak pengelola masih belum memahami sepenuhnya tentang pentingnya memenuhi hak-hak difabel atau kesetaraan bagi difabel, atau mungkin sama sekali tidak mengerti tentang hal-hal terkait dengan kesetaraan bagi difabel sehingga kemudian kekurangan-kekurangan diatas terjadi. Informasi dan komunikasi juga menjadi faktor yang mempengaruhi keberhasilan atau kegagalan suatu pelaksanaan kebijakan. Tidak diimplementasikannya 
aturan dengan baik juga dimungkinkan terjadi karena kebijakan yang ada tidak disosialisasikan dengan baik dan menyeluruh dari pemerintah, atau pemerintah tidak memberi himbauan kepada pihak pengelola wisata terkait dengan pelaksanaan dari Peraturan Menteri Pekerjaan Umum No.30 Tahun 2006 ini sehingga menjadikan pihak pengelola tidak menerapkan atau menyediakan fasilitas sesuai dengan aturan. Atau kegagalan dari implementasi Peraturan Menteri Pekerjaan Umum No.30 Tahun 2006 karena belum adanya kebijakan operasional dari peraturan menteri diatas atau kebijakan operasional yang mengatur secara khusus tentang penyediaan fasilitas dan sarana yang aksesibel bagi difabel di Kota Surakarta Kemungkinan lainnya adalah ketidaktersediaan sumber dana yang menjadikan tidak terpenuhinya fasilitasfasilitas yang dibutuhkan bagi difabel ini, meskipun pihak pengelola telah mengetahui dan memahami aturan yang ada.

Tidak tersedianya fasilitas yang aksesibel di lokasi wisata bagi difabel mempengaruhi penilaian tentang ketersediaan aksesibilitas bagi difabel dalam bidang pariwisata.Sesuai dengan tujuan yang ada, aksesibilitas pada dasarnya disediakan untuk mewujudkan kemandirian dan menciptakan lingkungan binaan yang ramah bagi semua orang, termasuk penyandang cacat. Namun apabila aksesibilitas pariwisata tidak tersedia bagi difabel, maka tidak akan terjadi kemandirian dan menyebabkan lingkungan tidak ramah difabel. Padahal difabel memiliki hak-hak yang tercantum dalam Undang-Undang No 4 Tahun 1997 dimana aksesibilitas menjadi salah satu hak yang dimiliki dan harus didapat oleh difabel.Tidak mampunya pemerintah dalam pemenuhan hak difabel menyebabkan munculnya pemikiran bahwa masih ada diskriminasi terhadap kaum difabel.

\section{Penutup}

Dari hasil penelitian dapat disimpulkan bahwa fasilitas dan sarana yang ada di lokasi wisata yang ada di Surakarta yakni Taman Balekambang, Taman Satwa Taru Jurug dan Taman Hiburan Rakyat (THR) Sriwedari tidak tersedia dengan baik secara keseluruhan sesuai dengan Peraturan Menteri Pekerjaan Umum No. 30 Tahun 2006 Tentang Pedoman Teknis Fasilitas dan Aksesibilitas Pada Bangunan Gedung dan Lingkungan. Ada beberapa fasilitas yang tersedia dengan baik dan sesuai dengan aturan yakni ukuran dasar ruang yang ada di Taman Balekambang dan Taman Satwa Taru Jurug, jalur pedestrian yang ada di Taman Balekambang, serta ramp yang ada di Taman Balekambang dan Taman Hiburan Rakyat (THR) Sriwedari. Selebihnya fasilitas yang harusnya tersedia sesuai dengan Peraturan Menteri Pekerjaan Umum No. 30 Tahun 2006 tidak disediakan dengan baik. Fasilitas yang tidak tersedia dengan baik adalah ukuran dasar ruang yang ada di Taman Hiburan Rakyat (THR) Sriwedari; Jalur pedestrian yang ada di Taman Satwa Taru Jurug dan Taman Hiburan Rakyat (THR) Sriwedari ; jalur pemandu, area parkir serta rambu dan marka di Taman Balekambang, Taman Satwa Taru Jurug dan Taman Hiburan Rakyat (THR) Sriwedari ; dan penyediaan ramp di Taman Satwa Taru Jurug.

Fasilitas dan sarana bagi difabel yang telah disediakan juga tidak seluruhnya aksesibel. Ukuran dasar ruang yang ada di Taman Balekambang dan Taman Satwa Taru Jurug saja yang dapat dikatakan aksesibel bagi difabel. Fasiltas lainnya yang aksesibel adalah jalur pedestrian yang ada di Taman Balekambang. Sehingga dapat disimpulkan bahwa aksesibilitas fasilitas dan sarana yang ada di lokasi wisata yang telah disebutkan sebelumnya belum aksesibel bagi difabel sehingga kesimpulan secara keseluruhan didapat bahwa pariwisata di Kota Surakarta belum aksesibel bagi 
Rina Herlina Haryanti, Candra Sari: Aksesibilitas Pariwisata Bagi Difabel di Kota Surakarta (Studi Evaluasi Peraturan Menteri Pekerjaan Umum Nomor 30 Tahun 2006 Tentang Pedoman Teknis Fasilitas Dan Aksesibilitas Pada Bangunan Gedung Dan Lingkungan)

difabel.

Dari hasil-hasil penelitian yang dilakukan, didapatkan temuan bahwa implementasi kebijakan ini telah gagal dalam menerapkan fungsi kepatuhan yang kemudian dilihat beberapa kemungkinan yang menyebabkan kegagalan itu terjadi antara lain kurangnya pemahaman dari pengelola maupun kurangnya penyediaan data terkait dengan fasilitas yang aksesibel. Tidak adanya kebijakan operasional dan dana juga menjadi kemungkinan terjadinya kegagalan implementasi kebijakan.

Setelah ditarik kesimpulan dan melihat keadaan yang ada di lokasi wisata yang ada di Surakarta maka penulis memberikan beberapa saran yang diharapkan dapat mendorong pihak pengelola maupun pemerintah untuk memenuhi kebutuhan bagi difabel sehingga dapat membuat pariwisata di Surakarta lebih aksesibel. Saran tersebut antara lain :

1. Jalur pedestrian yang ada di Taman Satwa Taru Jurug dan Taman Hiburan Rakyat (THR) Sriwedari segera diperbaiki agar lebih aksesibel, serta wajib dilengkapi dengan penyediaan bidang landai atau rampsesuai dengan Peratuan Menteri Pekerjaan Umum No 30 Tahun 2006.

2. Toilet khusus difabel bagi difabel meskipun hanya satu tempat untuk Taman Satwa Taru Jurug dan Taman Hiburan Rakyat (THR) Sriwedari harus segera disediakan. Toilet yang disediakan berukuran luas dan memiliki wc duduk sesuai dengan Peratuan Menteri Pekerjaan Umum No 30 Tahun 2006.

3. Untuk ketiga lokasi wisata yakni Taman Balekambang, Taman Satwa Taru Jurug dan Taman Hiburan Rakyat (THR) Sriwedari segara dipasang rambu dan marka yang menunjukkan area-area bagi difabel sehingga membantu difabel untuk menuju tempat tertentu.

4. Penyediaan ramp diperbanyak di beberapa area pada Taman Hiburan Rakyat (THR) Sriwedari dan dibuat landai sehingga memudahkan bagi difabel apabila ada jalur yang berundak. Sebab penyediaan ramp ini sangat bermanfaat bagi difabel khususnya pengguna kursi roda. Untuk Taman Satwa Taru Jurug juga secepatnya diberi ramp sebab seluruh area belum memiliki ramp.

5. Bagi pengelola di ketiga lokasi wisata yakni Taman Balekambang, Taman Satwa Taru Jurug dan Taman Hiburan Rakyat (THR) Sriwedari perlu melakukan pendataan inventaris apa saja yang dimiliki oleh lokasi wisata yang disediakan bagi difabel sehingga hal ini dapat mempermudah untuk dilakukan penilaian fasilitas mana yang belum tersedia sesuai dengan aturan.

6. Bagi pemerintah, penyediaaan dana terkait pengadaan pariwisata yang aksesibel juga menjadi hal yang penting agar penyediaan fasilitas bagi difabel dapat dilaksanakan dengan baik.

Penelitian ini telah dilakukan sesuai dengan metode yang digunakan. Namun terdapat beberapa keterbatasan dalam melakukan penelitian ini antara lain :

1. Paradigma atau cara pandang terhadap difabel masih menggunakan cara pandang lama dimana difabel diakui sebagai warga negara yang memiliki hak untuk menikmati hidup dengan segala fasilitas yang ada (Civil Right Model). Saat ini paradigma yang berkembang adalah Social Model dimana difabel 
adalah bagian dari masyarakat, mereka terlahir dalam masyarakat sehingga sudah selayaknya mereka hidup bersama masyarakat secara wajar. Paradigma yang baru ini menjadi rekomendasi untuk penelitian selanjutnya. Meskipun fokus penelitiannya sama namun dapat menggunakan cara pendang berbeda sehingga terdapat kebaruan dalam penelitian selanjutnya.

2. Informan yang digunakan dalam penelitian masih sangat terbatas. Di dalam penelitian ini difabel yang menjadi informan hanya penyandang tuna dhaksa. Padahal terdapat banyak klasifikasi disabilitas, sehingga dalam penelitian ini dapat dikatakan masih kurng beragam. Dalam penelitian selanjutnya direkomendasikan untuk melihat informan dari berbagai klasifikasi disabilitas sehingga data dan informasi yang dihasilkan lebih valid.

\section{Daftar Pustaka}

Darcy, S., \& Dickson, T. 2009. A WholeOf-Life Approach To Tourism: The Case For Accessible Tourism Experiences. Journal of Hospitality and Tourism Management, 16(1), 3244.

Demartoto, Argyo. 2005. Menyibak Sensitivitas Gender dalam Keluarga Difabel.Surakarta : Sebelas Maret University Press

Juliartha, Edward. 2009. Model Implementasi Kebijakan Publik. Jakarta : Trio Rimba Persada

Ladner, Richard. 2014. Broadening Participation : The Impact of the
United Nations Convention on the Rights og Persons with Disabilities. Jurnal Communications Of The Acm, Vol. 57 No.3.

Nielsen, Holly. 2013. Ability Beyond Disability : Understanding Accessibility. Public Relation Tactics on www.ebscohost.com

Solichin, Abdul Wahab. 1997. Evaluasi Kebijakan Publik. Malang : Penerbit FIA UNIBRAW dan IKIP

Spillane, James J.. 1994. Pariwisata Indonesia : Siasat Ekonomi Dan Rekayasa Kebudayaan. Yogyakarta : Penerbit Kanisius

Tarsidi, Didi. 2009. Penyandang Ketunaan - Istilah Pengganti Penyandang Cacat dalam http://pertuni.idpeurope.org/

Wibawa, Samodra. dkk. 1994. Evaluasi Kebijakan Publik. Jakarta : Raja Grafindo Persada.

Winarno, Budi. 2008. Kebijakan Publik: Teori dan Proses. Yogyakarta : Penerbit MedPress

Peraturan Menteri Pekerjaan Umum Nomor 30 Tahun 2006 Tentang Pedoman Teknis Fasilitas dan Aksesibilitas Pada Bangunan Gedung dan Lingkungan

Undang-Undang Negara Republik Indonesia Nomor 4 Tahun 1997 tentang Penyandang Cacat

Undang-Undang Republik Indonesia Nomor 10 Tahun 2009 tentang Kepariwisataan 